\title{
STUDI META-ANALISIS PENERAPAN TEORI PENETRASI SOSIAL PADA PERKEMBANGAN HUBUNGAN DALAM PERNIKAHAN BERDASARKAN PERJODOHAN SYARIAT ISLAM (TA'ARUF)
}

\author{
Shavira Hanza Renadia, Filza Alifah Hasny dan Irwansyah \\ Universitas Indonesia, Depok, Jawa Barat, Indonesia \\ Email: shavira.hanza@ui.ac.id, filza.alifah@ui.ac.id dan irwansyah09@ui.ac.id
}

\begin{abstract}
This meta-analysis study aims to determine the differences from previous research in social penetration theory. This journal focuses on the correlation between the ta'aruf marriage process with the relationship development process with the stages and assumptions of social penetration theory. The development of relationships based on good interpersonal communication and self-disclosure of relationships can affect the results of the stability exchange of relationships amongs the couple. This journal explains that the process of social penetration has affected stability in ta'aruf marriage. The method used in this study is qualitative with a statistical approach that practices it in organizing a certain amount of information derived from large samples whose functions are to complement other purposes. The results obtained in this study are the layers or stages and processes of social penetration that occur during the process of introduction before marriage or commonly called Ta'aruf in Islam.
\end{abstract}

Keywords: social penetration; relationship development; communication; interpersonal; ta'aruf; marriage

\begin{abstract}
Studi meta analisis ini bertujuan untuk mengetahui perbedaan hasil penelitian dalam membahas teori penetrasi sosial yang telah dilakukan. Artikel ini berfokus pada keterkaitan proses pernikahan ta'aruf dengan tahapan proses perkembangan hubungan dengan penetrasi sosial dan asumsi - asumsi dasar dari teori penetrasi sosial. Perkembangan hubungan akan berjalan dengan sistematis dan dengan komunikasi interpersonal yang baik serta keterbukaan diri hubungan dapat mempengaruhi tingkat stabilitas hubungan. Jurnal ini menjelaskan proses penetrasi sosial telah mempengaruhi pertukaran stabilitas di dalam pernikahan ta'aruf. Metode yang digunakan dalam penelitian ini adalah kualitatif dengan pendekatan statistik yang mempraktekkannya dalam mengorganisasikan sejumlah informasi yang berasal dari sampel besar yang fungsinya untuk melengkapi maksud-maksud lainnya. Hasil yang diperoleh dalam penelitian ini yaitu adanya lapisan atau tahapan serta proses penetrasi sosial yang terjadi selama proses pengenalan sebelum menikah atau yang biasanya disebut Ta'aruf dalam agama Islam.
\end{abstract}

Kata Kunci: penetrasi social; perkembangan hubungan; komunikasi; interpersonal ; ta'aruf; pernikahan 
Coresponden Author

Email: shavira.hanza@ui.ac.id

Artikel dengan akses terbuka dibawah lisensi

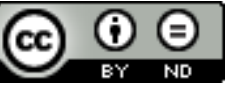

\section{Pendahuluan}

Ta'aruf tidak seperti pacaran pada umumnya, hubungan yang dibangun pada hubungan ta'aruf ini membutuhkan waktu yang singkat. Hubungan hanya berlangsung beberapa bulan atau bahkan bisa beberapa minggu sebelum pernikahan. Komunikasi antara calon pasangan dibatasi untuk menghindari kontak langsung antara lawan jenis. Frekuensi interaksi dan waktu hubungan yang singkat seringkali menyebabkan topik mengenai perbedaan nilai budaya tidak muncul di permukaan. Kedua individu benarbenar mengenal satu sama lain setelah mereka menikah. Kecenderungan timbulnya konflik setelah menikah dapat meningkat karena mereka tidak hanya harus beradaptasi secara pribadi tetapi juga sebagai individu dengan identitas budaya yang berbeda.

Menurut jurnal yang ditulis oleh (Tryssa \& Zarkasi, 2018), Keyakinan agama yang memotivasi mereka untuk memilih ta'aruf daripada kencan konvensional. Mereka sangat percaya bahwa Tuhan lebih menyukai dan meridhoi proses ta'aruf daripada kencan konvensional yang menurut mereka dapat dengan mudah mengarah pada perzinahan. Kesamaan dalam keyakinan serta ekspektasi dianggap lebih bermanfaat daripada penampilan fisik.

Teori Penetrasi Sosial ini penulis yakini penting sekali secara konsep dan kontekstual dalam mengkaji fenomena pernikahan yang didasarkan pada perjodohan atau Ta'aruf. Pada teori Penetrasi Sosial, akan dibahas tuntas sebuah proses komunikasi yang terjadi pada hubungan pernikahan antara dua individu yang melewati proses ta'aruf secara efisien dan berlapis. Dengan menggunakan teori Penetrasi Sosial ini kita dapat memahami hubungan Ta'aruf yang terjadi antara dua individu secara lebih mendalam melalui lapisan-lapisan hubungan atau keintiman yang dikaji pada Teori Penetrasi Sosial.

Teori Penetrasi Sosial pertama kali dijabarkan oleh Irwin Altman \& Dalmas Taylor pada tahun 1973. Pada tahun tersebut kehidupan sosial di Amerika Serikat mengalami berbagai perubahan, ada lebih banyak penekanan, keterbukaan dan kebebasan relasional dalam hubungan personal mereka. Dalam merespon adanya perubahan tersebut, para peneliti mengembangkan beberapa teori untuk mengeksplorasi bagaimana keterbukaan diri dapat meningkatkan derajat keintiman dalam sebuah hubungan. (Altman \& Taylor, 1973) menyatakan bahwa sebuah hubungan interpersonal seseorang akan berakhir dengan baik dan intim jika kedua belah pihak melewati lintasan lintasan dan lapisan penting pada komunikasi untuk mencapai sebuah kedekatan dalam berhubungan.

Altman \& Taylor mengumpamakan lapisan lapisan tersebut seperti pada lapisan bawang, di mana lapisan terluar digambarkan seperti citra publik atau informasi dan 
fakta yang dapat dilihat secara langsung, seperti bentuk fisik, nama, umur dan lainnya, yang seiring dengan berjalannya waktu akan terkelupas saat seseorang mulai membuka diri dan membuka informasi tentang dirinya lebih dalam dari sekedar informasi umum. Resiprositas akan dicapai ketika kedua individu sudah saling terbuka satu sama lainnya. Resiprositas adalah kondisi di mana keterbukaan diri mempengaruhi orang lain untuk ikut terbuka. Keintiman tidak dapat dicapai tanpa Resiprositas.

Menurut (West \& Turner, 2014) ada 4 tahapan pada Penetrasi Sosial:

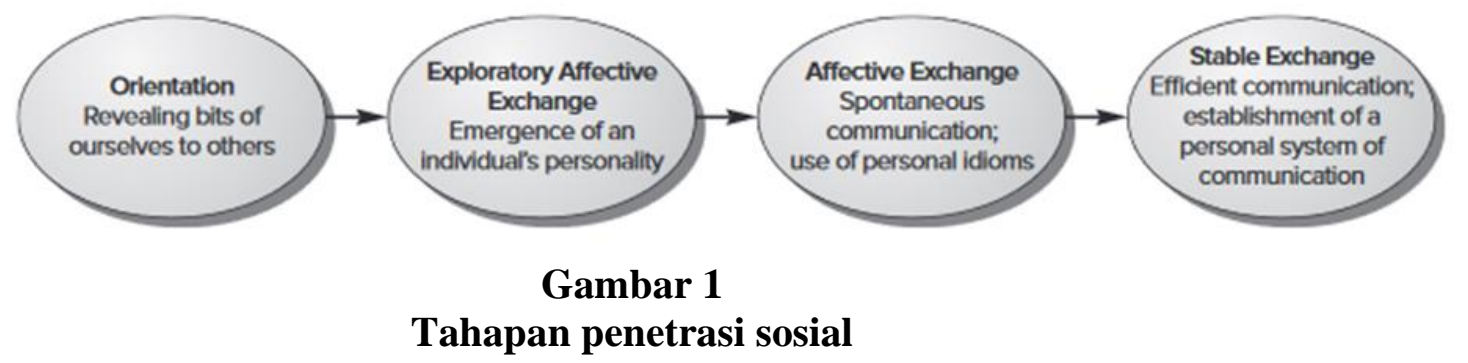

Pertama, Tahap Orientasi yaitu tahap awal / tahap perkenalan. Pada tahapan ini kita tidak begitu mengetahui sisi pribadi seseorang karena yang tampak hanya dari luarnya saja. Percakapan hanya sebatas basa-basi dan membicarakan seputar informasi umum. Menurut Altman dan Taylor yang dikutip oleh Wulandari (Wulandari \& Subagio, 2015), Jika tahapan ini berjalan dengan lancar dan tercapai sebuah interaksi yang dibutuhkan maka mereka akan melanjutkan ke tahap berikutnya.

Kedua, Tahap Pertukaran Penjajakan Afektif. Tahap ini merupakan tahapan lanjutan awal dari informasi dasar ke informasi yang lebih mendalam. Dalam tahap ini, kedua individu mulai membicarakan hal-hal yang disukai dan menarik perhatian masing-masing seperti hobi, kesukaan makanan, kebiasaan dan lainnya. Mereka mulai menunjukan hal-hal yang sifatnya pribadi. Banyak fakta atau informasi yang tadinya merupakan hal pribadi berubah menjadi hal yang umum. Gaya bahasa dan pilihan kata yang dipilih juga menjadi lebih personal atau akrab. Komunikasi yang terjadi menjadi lebih spontan karena kedua individu sudah mulai terbiasa dan nyaman satu dengan lainnya. Pengungkapan seseorang mulai muncul karena lawan bicara pun sudah lebih leluasa untuk mengungkapkan sesuatu. Pada tahapan ini, perilaku sentuhan atau ekspresi emosi juga mulai terbangun. Tahapan ini merupakan tahapan penting yang menentukan seseorang untuk masuk ke tahapan berikutnya.

Ketiga, Tahap Pertukaran Afektif. Pada tahap ini hubungan kedua belah pihak menjadi lebih intim dan adanya pertukaran informasi pribadi yang lebih intens. Informasi yang dimaksud seperti informasi mengenai pengalaman pribadi masingmasing. Timbul kesediaan untuk menceritakan tentang masalah pribadi dan kedua individu sudah berani untuk mulai mencurahkan isi hati masing-masing. Dalam tahap ini juga terjadi pertukaran pendapat dan saling kritik, meskipun begitu, masih banyak individu yang berusaha untuk melindungi diri mereka dengan tidak mengungkapkan informasi yang sifatnya terlalu sensitif. 
Keempat, Tahap Pertukaran Stabil. Menurut (West \& Turner, 2014) menjabarkan komunikasi yang ada sudah bersifat efisien, jelas dan tidak ambigu. Selain itu komunikasi antar kedua belah pihak sifatnya sudah sangat dalam intim. Percakapannya sudah meliputi nilai, konsep diri, atau perasaan dan juga emosi mendalam. Keduanya sudah saling mengerti dan memahami perasaan masing-masing. Penelitian yang dilakukan (Tryssa \& Zarkasi, 2018) juga sudah sangat menjelaskan proses orientasi, pertukaran afektif eksploratif, pertukaran afektif dan pertukaran stabilitas.

Asumsi dasar dari Teori Penetrasi Sosial dalam (West \& Turner, 2014) Hubungan mengalami kemajuan dari tidak intim menjadi intim. Hubungan komunikasi antar seseorang dimulai dari tahapan dasar dan bergerak menuju ke yang lebih intim. tidak semua hubungan jatuh ke ekstrem tidak intim atau intim. Faktanya, banyak dari hubungan kita berada di antara dua kutub ini. Seringkali, kita mungkin hanya menginginkan hubungan yang cukup dekat.

Perkembangan hubungan sistematis dan dapat diprediksi. Hubungan komunikasi yang terjadi antar manusia berkembang secara sistematis dan dapat diprediksi. Memang, proses komunikasi bersifat dinamis dan terus berubah, namun hubungan yang dinamis akan tetap mengikuti standar dan pola perkembangan yang dapat diterima. Proses penetrasi sosial dapat dibilang cukup teratur dan dapat diduga. Tentu, beberapa variabel seperti waktu, kepribadian, dan lain nya mempengaruhi perkembangan hubungan seseorang.

Perkembangan hubungan mencakup depenetrasi (penarikan diri) dan disolusi. Sebuah hubungan dapat menjadi kacau atau istilahnya menarik diri (depenetrasi) dan hal ini dapat menyebabkan terjadinya disolusi hubungan. Altman \& Taylor menyatakan kemiripan proses ini dengan sebuah film yang diputar mundur. Komunikasi memungkinkan sebuah hubungan untuk bergerak maju dan mundur. Sebuah komunikasi atau hubungan yang penuh konflik akan menjadi destruktif dan tidak bisa diselesaikan. Namun, hal ini bukan berarti hubungan yang ada menjadi hilang total atau berakhir, Hubungan akan mengalami Transgresi (Transgression) yaitu pelanggaran pelaksanaan dan harapan dalam berhubungan. Transgresi ini mungkin seperti tidak dapat selesai dan memang seringkali seperti ini.

Self-disclosure (pengungkapan diri) adalah inti dari perkembangan hubungan. Self disclosure adalah suatu proses pembukaan informasi diri kepada orang lain dengan tujuan tertentu. Menurut Altman \& Taylor hubungan dapat bergerak dari titik tidak intim ke titik yang intim karena adanya keterbukaan diri. Proses ini memungkinkan seseorang untuk saling mengenal satu sama lain. Asumsi ini juga dikemukakan pada jurnal yang ditulis oleh (Kinanthi \& Sakinah, 2018). Semakin tinggi tingkat keterbukaan diri seseorang, maka semakin tinggi pula kepuasan pernikahan yang dialami individu.

Penelitian terdahulu yang dilakukan oleh (Agustin Wulandari, 2013) menyebutkan Social Penetration Theory (SPT) merupakan sebuah teori yang menggambarkan suatu pola pengembangan hubungan. Teori penetrasi sosial juga menjelaskan bahwa dengan berkembangnya hubungan, keluasan dan kedalaman percakapan akan meningkat (Shanaz, 2021). Praktek penggunaan teori Penetrasi Sosial dapat dilihat dari berbagai 
fenomena dan kasus-kasus kontemporer di Indonesia. Contohnya pada fenomena pernikahan beda agama, beda suku, fenomena hubungan antar pemain game online, dan masih banyak lagi. Pada kesempatan kali ini, penulis akan membahas tuntas tentang aplikasi teori penetrasi sosial pada pernikahan yang dijodohkan atau biasa kita sebut sebagai ta'aruf dalam agama islam. Topik ini menarik karena hubungan yang dijodohkan melalui seluruh proses dari teori penetrasi sosial itu sendiri. Dari mulai penjajakan awal hingga pada akhirnya berlabuh di pernikahan antara dua individu yang tidak mengenal satu dengan lain. Tentunya banyak proses dan lapisan yang dilewati oleh kedua individu tersebut sampai akhirnya dapat melangsungkan pernikahan. Tugas utama penelitian ilmiah adalah menemukan kebenaran ilmiah yang sifatnya objektif, dapat diverifikasi dan dikomunikasikan untuk memenuhi fungsinya, yaitu: membuat deskripsi, menjelaskan, pengembangan teori, membuat prediksi serta melakukan kontrol (Suryabrata, 1998). Tujuan dari penelitian ini adalah untuk mengetahui perbedaan hasil penelitian dalam membahas teori penetrasi sosial yang telah dilakukan, adapun manfaat yang bisa diambil yakni diharapkan penelitian ini mampu menjadi pembanding bagi penelitian selanjutnya yang akan dilakukan.

\section{Metode Penelitian}

Menurut (Siddiqi \& Glass, 1981) meta analisis merupakan analisis kuantitatif dan menggunakan sejumlah data yang cukup banyak serta menerapkan metode statistik dengan mempraktekkannya dalam mengorganisasikan sejumlah informasi yang berasal dari sampel besar yang fungsinya untuk melengkapi maksud-maksud lainnya. Metaanalisis tampil mengatasi persoalan penelitian dalam bidang-bidang ilmu-ilmu sosial termasuk pada ilmu komunikasi. Untuk dapat memenuhi fungsi ilmiah, hasil-hasil penelitian memerlukan suatu metode ilmiah yang sistematis untuk mengintegrasikan temuan - temuan atau hasil-hasil penelitian.

Penulisan ini disusun menggunakan Teori Penetrasi Sosial yang dikemukakan oleh Altman dan Taylor sebagai kerangka teori untuk memahami hubungan pernikahan yang didasari dari hubungan perjodohan atau sering disebut sebagai Ta'aruf. Teori Penetrasi Sosial didasarkan pada asumsi bahwa ketika individu-individu dalam hubungan mengungkapkan diri satu sama lain, maka tahapan-tahapan hubungan akan berkembang juga sejalan dengan waktu dan intensitas komunikasi. Altman dan Taylor menggunakan istilah bawang merah sebagai metafora untuk menggambarkan perkembangan hubungan dalam hubungan interpersonal. Hubungan, layaknya seperti bawang, memiliki banyak lapisan, semakin banyak lapisan yang dikupas, semakin dalam dan semakin intim suatu hubungan tersebut.

Pemilihan jurnal yang diteliti pada kajian meta analisis ini terfokus pada jurnal dengan kriteria seperti berikut :

1. Jurnal internasional dan nasional

2. Penelitian dilakukan pada tahun 2010 hingga tahun 2020

3. Obyek penelitian berupa proses pengembangan hubungan pada pasangan ta'aruf yang sukses melakukan pernikahan 
Peneliti menganalisa tiga jurnal yang akan dikaji dengan metode kualitatif dengan pendekatan analisis isi.

Tabel 1

Kajian pustaka

\begin{tabular}{|c|c|c|c|}
\hline Judul dan Peneliti & Obyek & Metode & Hasil \\
\hline $\begin{array}{c}\text { Communication in } \\
\text { Intercultural Marriage: } \\
\text { The Application of Social } \\
\text { Penetration Theory } \\
\text { among Couples Preceded } \\
\text { by Ta'aruf oleh Shinta } \\
\text { Galuh \& Irwa R. Zakarsi } \\
\text { (2014) } \\
\text { https://sinta.ristekbrin.go.id } \\
\text { /affiliations/detail?page=83 } \\
\text { \&id=1089\&view=docume } \\
\text { nts }\end{array}$ & $\begin{array}{l}\text { Pada jurnal ini telah dua } \\
\text { pasangan yang telah } \\
\text { melalui proses ta'aruf dan } \\
\text { menikah. Penelitian ini } \\
\text { melihat bagaimana proses } \\
\text { sebuah penetrasi sosial } \\
\text { dalam mengembangkan } \\
\text { sebuah hubungan hingga } \\
\text { ke tahap stabil. }\end{array}$ & $\begin{array}{c}\text { Metode penelitian dengan } \\
\text { metode kualitatif dengan } \\
\text { teknik wawancara dan } \\
\text { studi dokumen tertulis. } \\
\text { Data dikumpulkan } \\
\text { berdasarkan in-depth } \\
\text { interview dan tinjauan } \\
\text { literatur. }\end{array}$ & $\begin{array}{c}\text { Dalam perkembangan } \\
\text { hubungan dengan ta'aruf, } \\
\text { kecocokan dalam konteks } \\
\text { fisik minimal namun lebih } \\
\text { menitikberatkan pada } \\
\text { kesamaan kepercayaan dan } \\
\text { nilai. } \\
\text { Teori penetrasi sosial dapat } \\
\text { diaplikasikan dalam } \\
\text { perkembangan hubungan } \\
\text { dengan proses ta'aruf. } \\
\text { Dimensi latar belakang } \\
\text { budaya dari masing - } \\
\text { masing pasangan } \\
\text { mempengaruhi tahapan } \\
\text { orientasi }\end{array}$ \\
\hline $\begin{array}{c}\text { Pengungkapan Diri dan } \\
\text { Kepuasan Pernikahan } \\
\text { pada Individu yang } \\
\text { Menikah Melalui Proses } \\
\text { Ta'aruf oleh Fitri Sakinah } \\
\text { dan Melok Roro Kinanthi } \\
\text { (2018) } \\
\text { http://ejournal.uin- } \\
\text { suka.ac.id/isoshum/PI/artic } \\
\text { le/view/1466 }\end{array}$ & $\begin{array}{l}\text { Pada jurnal ini telah } \\
\text { meneliti } 88 \text { orang yang } \\
\text { telah menikah dengan } \\
\text { proses ta'aruf. Penelitian } \\
\text { ini melihat bagaimana } \\
\text { konsep keterbukaan diri } \\
\text { (self disclosure) dapat } \\
\text { mempengaruhi kehidupan } \\
\text { pasca pernikahan pada } \\
\text { konsep kepuasan } \\
\text { pernikahan. } \\
\text { variabel yang diteliti : } \\
\text { pengaruh self disclosure } \\
\text { pada pasangan ta'aruf } \\
\text { dapat mempengaruhi } \\
\text { kepuasan pernikahan. }\end{array}$ & $\begin{array}{c}\text { Metode penelitian dengan } \\
\text { pendekatan kuantitatif } \\
\text { yang digunakan dengan } \\
\text { desain asosiatif. Teknik } \\
\text { pengambilan sampel } \\
\text { menggunakan accidental } \\
\text { sampling. kemudian data } \\
\text { diolah dengan analisis } \\
\text { statistik deskriptif, uji } \\
\text { normalitas dengan teknik } \\
\text { Kolmogorov - Smirnov, uji } \\
\text { linieritas, dan uji hipotesis } \\
\text { dengan analisis regresi } \\
\text { sederhana. }\end{array}$ & $\begin{array}{c}\text { Terdapat peran } \\
\text { pengungkapan diri } \\
\text { terhadap kepuasan } \\
\text { pernikahan pada individu } \\
\text { yang menikah melalui } \\
\text { ta'aruf. }\end{array}$ \\
\hline $\begin{array}{l}\text { Proses Komunikasi } \\
\text { Interpersonal dalam }\end{array}$ & $\begin{array}{l}\text { Pada jurnal ini telah } \\
\text { meneliti lima pasangan }\end{array}$ & $\begin{array}{l}\text { Metode penelitian dengan } \\
\text { pendekatan kualitatif. }\end{array}$ & $\begin{array}{l}\text { Tahap orientasi adalah } \\
\text { tahap dimana komunikasi }\end{array}$ \\
\hline
\end{tabular}




\begin{tabular}{|c|c|c|c|}
\hline $\begin{array}{c}\text { Ta'aruf di Banda Aceh } \\
\text { oleh Ridwansyah (2018) } \\
\text { http://jurnal.unsyiah.ac.id/J } \\
\text { KG/article/view/10566 }\end{array}$ & $\begin{array}{c}\text { yang telah menikah dengan } \\
\text { proses ta'aruf }\end{array}$ & $\begin{array}{c}\text { Penelitian ini } \\
\text { menggunakan metode } \\
\text { deskriptif kualitatif. Teknik } \\
\text { pengumpulan data dalam } \\
\text { penelitian ini } \\
\text { menggunakan metode } \\
\text { wawancara mendalam } \\
\text { dengan teknik pemilihan } \\
\text { informan dilakukan secara } \\
\text { non-probabilitas dengan } \\
\text { menggunakan teknik } \\
\text { purposive. }\end{array}$ & $\begin{array}{l}\text { yang terjadi pada saat } \\
\text { ta’aruf lebih pada hal-hal } \\
\text { yang bersifat umum dari } \\
\text { masing masing pihak. } \\
\text { Tahapan afektif } \\
\text { eksploratif, tahapan afektif } \\
\text { dan tahapan pertukaran } \\
\text { stabil dilakukan setelah } \\
\text { menikah. }\end{array}$ \\
\hline
\end{tabular}

Pada penulisan kali ini, penulis akan menggunakan pendekatan kualitatif yang berdasar pada kumpulan artikel dan juga jurnal terkait sesuai dengan konteks dan kasus yang akan dibahas. Jurnal pertama, yang ditulis oleh (Tryssa \& Zarkasi, 2018) berjudul Communication in Intercultural Marriage: The Application of Social Penetration Theory among Couples Preceded by Ta'aruf membahas lebih mendalam tentang fenomena pernikahan Ta'aruf dan proses komunikasi yang dialami oleh dua narasumber FH-FS dan AN-IL. Penelitian ini bertujuan untuk mengetahui bagaimana teori penetrasi sosial yang diterapkan dalam perkawinan antar budaya yang didahului dengan ta'aruf. Lebih lanjut, tujuan penelitian ini adalah untuk melihat bagaimana hubungan yang berkembang pada pasangan suami istri di mana interaksi sebelum menikah dibatasi, dan di mana perbedaan budaya dapat mempengaruhi perkembangan tersebut.

Jurnal kedua ditulis oleh (Kinanthi \& Sakinah, 2018) yang berjudul Pengungkapan Diri dan Kepuasan Pernikahan pada Individu yang Menikah Melalui Proses Ta'aruf. Penelitian pada jurnal ini bertujuan untuk mengetahui peran selfdisclosure terhadap kepuasan pernikahan pada individu yang menikah melalui proses ta'aruf. Penelitian ini mengetengahkan bagaimana pengungkapan diri kepada pasangan dapat membantu individu untuk mencapai kehidupan pernikahan yang memuaskan. Self-disclosure merupakan salah satu asumsi dasar dari Teori Penetrasi Sosial.

Jurnal ketiga ditulis oleh (Ridwansyah, 2018) yang berjudul Proses Komunikasi Interpersonal dalam Ta'aruf di Banda Aceh. Penelitian pada jurnal ini meneliti lima pasangan yang telah menikah yang diawali dengan proses ta'aruf. Penelitian ini meneliti bagaimana proses hubungan dapat berkembang berdasarkan teori penetrasi sosial terutama pada tahap orientasi yang minim interaksi dan eksplorasi.

Ketiga jurnal ini menjadi pedoman penulis dalam memahami lebih lanjut aplikasi dari teori penetrasi sosial dalam pernikahan berdasarkan perjodohan. Temuan - temuan yang ada pada penelitian sebelumnya akan di analisis dari tahapan teori penetrasi sosial dan asumsi dasar teori penetrasi sosial. 
Studi Meta-Analisis Penerapan Teori Penetrasi Sosial pada Perkembangan Hubungan dalam Pernikahan Berdasarkan Perjodohan Syariat Islam (Ta'aruf)

\section{Hasil dan Pembahasan}

\section{A. Hasil Penelitian}

1. Tabel analisis

(Beebe, Beebe, Redmond, Geerinck, \& Salem-Wiseman, 2011) menyatakan bahwa hubungan asmara antara dua individu merupakan hubungan paling intim yang dapat dialami oleh seseorang. Dalam agama Islam, percintaan antara lawan jenis hanya difasilitasi dalam pernikahan. Seperti yang dikatakan Beebe dan Redmond, dalam pernikahan, hubungan antar individu sangatlah erat. Pasangan menghabiskan hubungan yang panjang, dalam, dan intens, dan melewati banyak peristiwa kehidupan bersama.

Peneliti akan menganalisis dengan analisis isi pada kedua jurnal dengan menggunakan unit analisis berdasarkan tahapan teori penetrasi sosial, yaitu ; orientasi, pertukaran dan penjajakan afektif, pertukaran afektif dalam melihat keberhasilan resiprokal dalam suatu proses Ta'aruf.

Tabel 2

Analisa Tahapan Teori Penetrasi Sosial

\begin{tabular}{|c|c|c|c|c|}
\hline Unit Analisis & $\begin{array}{l}\text { Subunit } \\
\text { Analisis }\end{array}$ & Ridwansyah (2018) & $\begin{array}{c}\text { Fitri Sakinah dan } \\
\text { Melok Roro Kinanthi } \\
(\mathbf{2 0 1 8 )}\end{array}$ & $\begin{array}{c}\text { Shinta Galuh \& Irwa } \\
\text { R. Zarkasi (2014) }\end{array}$ \\
\hline Orientasi & $\begin{array}{c}\text { Proses } \\
\text { Orientasi }\end{array}$ & $\begin{array}{c}\text { HM \& NI } \\
\text { Melakukan pertemuan } \\
\text { secara langsung dalam } \\
\text { konteks profesional } \\
\text { dalam sebuah } \\
\text { organisasi yang } \\
\text { mereka ikuti bersama } \\
\\
\text { MHR \& I } \\
\text { Melakukan pertemuan } \\
\text { didampingi oleh ketua }\end{array}$ & $\begin{array}{l}\text { Penelitian pada jurnal } \\
\text { ini tidak menjelaskan } \\
\text { proses orientasi }\end{array}$ & $\begin{array}{c}\text { FH \& FS } \\
\text { Perkenalan kedua } \\
\text { pasangan melalui } \\
\text { mediator sesuai syariat } \\
\text { Islam. FH dan FS } \\
\text { bertukar Curriculum } \\
\text { Vitae melalui e-mail } \\
\text { dengan mediator } \\
\text { masing - masing. } \\
\\
\text { AN \& IL } \\
\text { Perkenalan kedua } \\
\text { pasangan melalui } \\
\text { mediator. AN } \\
\text { dimediasi oleh } \\
\text { saudaranya dan IL } \\
\text { dimediasi oleh adik } \\
\text { kandungnya. Di dalam } \\
\text { jurnal tidak dijelaskan } \\
\text { proses pertukaran } \\
\text { profil kedua belah } \\
\text { pihak. }\end{array}$ \\
\hline
\end{tabular}


kelompok pengajian

Jurnal ini

menyimpulkan pada

proses Orientasi

terdapat pertukaran

informasi dasar seperti

nama, kegiatan dan

informasi - informasi

yang dapat diketahui

oleh publik

\begin{tabular}{ccc}
\hline Hasil Orientasi & $\begin{array}{c}\text { Lima pasangan ta'aruf } \\
\text { berlanjut pada tahapan } \\
\text { pertukaran eksploratif }\end{array}$ & Penelitian pada jurnal \\
afektif dikarenakan & hasil proses orientasi \\
telah menemukan & \\
kecocokan yang & \\
mendasar di dalam & \\
masing - masing & pasangan.
\end{tabular}

\section{FH \& FS}

Pada tahap orientansi narasumber melanjutkan proses pertemuan (nadzar) bersama muhrimnya karena berdasarkan CV yang telah diberikan ditemukan kecocokan

AN \& IL

Melanjutkan pertemuan bersama mediator masing masing.

\begin{tabular}{|c|c|c|c|c|}
\hline $\begin{array}{c}\text { Pertukaran } \\
\text { Penjajakan } \\
\text { Afektif }\end{array}$ & $\begin{array}{c}\text { proses } \\
\text { Pertukaran } \\
\text { Penjajakan } \\
\text { Afektif }\end{array}$ & $\begin{array}{c}\text { Kelima pasangan } \\
\text { melakukan pertemuan } \\
\text { dan pada tahapan ini } \\
\text { masing - masing pihak } \\
\text { diminta untuk } \\
\text { membuka diri dan } \\
\text { saling bertukar } \\
\text { informasi fundamental } \\
\text { terkait pernikahan. } \\
\text { tahapan ini } \\
\text { menentukan apakah } \\
\text { ta'aruf ini berlanjut } \\
\text { atau dihentikan. Kedua } \\
\text { belah pihak akan } \\
\text { melakukan istikharah } \\
\text { dan apabila hasilnya } \\
\text { positif maka akan }\end{array}$ & $\begin{array}{c}\text { Penelitian pada jurnal } \\
\text { ini tidak menjelaskan } \\
\text { proses Pertukaran } \\
\text { penjajakan Afektif }\end{array}$ & $\begin{array}{c}\text { FH \& FS } \\
\text { Setelah bertemu untuk } \\
\text { kedua kalinya dalam } \\
\text { memastikan kecocokan } \\
\text { dan melakukan } \\
\text { istikharah, keduanya } \\
\text { diilhami mimpi yang } \\
\text { sama. Pada tahapan ini } \\
\text { keduanya memiliki } \\
\text { izin dari masing - } \\
\text { masing orang tua. } \\
\text { stereotip suku minang } \\
\text { yang dimiliki FS } \\
\text { terhadap FH } \\
\text { menghilang sejak } \\
\text { pertemuan keluarga } \\
\text { besar terjadi. kedua }\end{array}$ \\
\hline
\end{tabular}




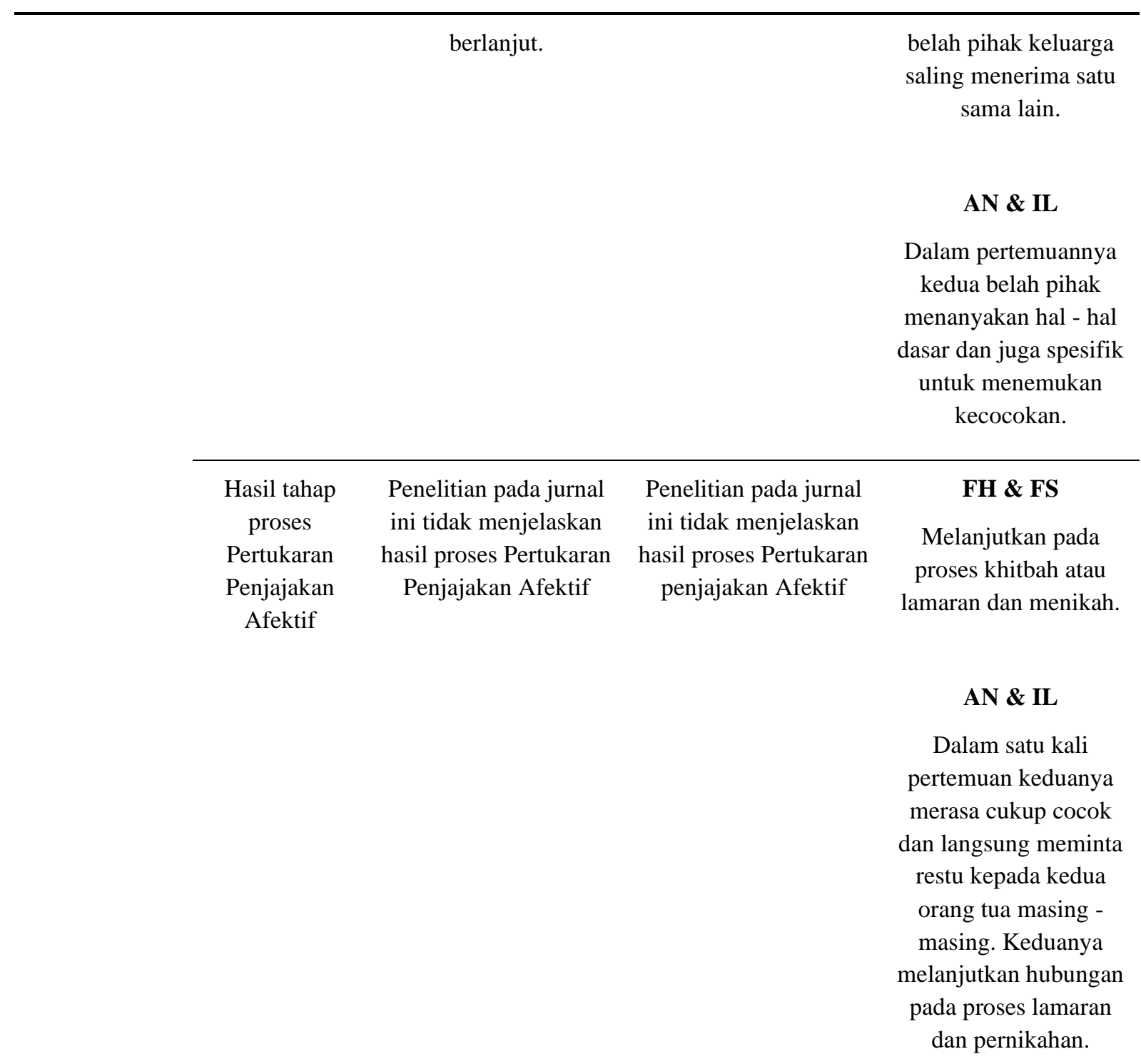

\begin{tabular}{cccc}
\hline Tahap & Proses & Penelitian pada jurnal & Penelitian pada jurnal \\
Pertukaran & Pertukaran & ini tidak menjelaskan & ini tidak menjelaskan \\
Afektif & Afektif & proses Pertukaran & proses Pertukaran \\
& & Afektif & Afektif
\end{tabular}

\section{FH \& FS}

FH secara terus terang menjelaskan apa yang tidak disukai olehnya dan FS memberikan

kritik kepada FH melalui e-mail untuk mengurangi konflik jika dikatakan secara langsung.

AN \& IL

Dalam proses pertukaran afektif keduanya memiliki 


\begin{tabular}{|c|c|c|c|}
\hline & \multirow{3}{*}{$\begin{array}{c}\text { penelitian pada jurnal } \\
\text { ini tidak menjelaskan } \\
\text { hasil proses Pertukaran } \\
\text { Afektif }\end{array}$} & \multirow{3}{*}{$\begin{array}{c}\text { penelitian pada jurnal } \\
\text { ini tidak menjelaskan } \\
\text { hasil proses Pertukaran } \\
\text { Afektif }\end{array}$} & $\begin{array}{c}\text { problem serta } \\
\text { perbedaan cara } \\
\text { pandang salah satunya } \\
\text { cara memandang } \\
\text { sebuah gaya hidup. }\end{array}$ \\
\hline & & & $\begin{array}{c}\text { FH \& FS } \\
\text { Menemukan solusi } \\
\text { dengan berpindah ke } \\
\text { tempat baru dimana } \\
\text { mereka tidak tinggal } \\
\text { bersama orangtua. }\end{array}$ \\
\hline & & & $\begin{array}{c}\text { AN \& IL } \\
\text { Berpindah ke } \\
\text { Makassar menjadikan } \\
\text { mereka lebih } \\
\text { independen }\end{array}$ \\
\hline $\begin{array}{c}\text { Pertukaran } \\
\text { Stabil }\end{array}$ & $\begin{array}{l}\text { Penelitian pada jurnal } \\
\text { ini tidak menjelaskan } \\
\text { hasil proses Pertukaran } \\
\text { Stabil }\end{array}$ & $\begin{array}{c}\text { Pada jurnal penelitian } \\
\text { ini menjelaskan bahwa } \\
\text { adanya kepuasan } \\
\text { individu yang telah } \\
\text { menikah melalui } \\
\text { proses ta'aruf yang } \\
\text { mengindikasikan } \\
\text { adanya pertukaran } \\
\text { stabil dalam hubungan } \\
\text { pernikahannya. hal ini } \\
\text { dikarenakan sejak awal } \\
\text { proses ta'aruf telah } \\
\text { ditemukan kecocokan } \\
\text { yang mendasar pada } \\
\text { proses self-disclosure. }\end{array}$ & $\begin{array}{c}\text { FH \& FS } \\
\text { Komunikasi mereka } \\
\text { (resiprokal) berjalan } \\
\text { membaik. } \\
\text { Permasalahan yang } \\
\text { dimiliki adalah isu } \\
\text { fertilitas dan kedua } \\
\text { belah pihak keluarga } \\
\text { terlibat dalam } \\
\text { mendukung dalam } \\
\text { program fertilitas ini. } \\
\\
\text { AN \& IL } \\
\text { Hubungan mereka } \\
\text { berkembang setelah } \\
\text { berpindah ke } \\
\text { Makassar. Karakter } \\
\text { dan kerelaan IL untuk } \\
\text { beradaptasi dengan } \\
\text { situasi kehidupan } \\
\text { setelah pernikahan } \\
\text { yang berbeda dengan } \\
\text { kehidupannya sebelum } \\
\text { menikah menjadikan } \\
\text { keduanya bertahan. }\end{array}$ \\
\hline
\end{tabular}




\begin{tabular}{cc}
\hline $\begin{array}{c}\text { Penelitian pada jurnal } \\
\text { ini tidak menjelaskan } \\
\text { hasil proses Pertukaran } \\
\text { Stabil }\end{array}$ & FH FS \\
Kedua belah pihak \\
mempertahankan \\
stabilitas hubungan \\
dan melanjutkan \\
pernikahan dengan \\
saling memahami \\
perasaan satu sama \\
lain. \\
AN \& IL \\
Kedua belah pihak \\
mempertahankan \\
stabilitas hubungan \\
dan melanjutkan \\
pernikahan dengan \\
menghormati dan \\
merelakan keputusan \\
satu sama lain
\end{tabular}

Dalam menganalisa lebih lanjut mengenai keberhasilan dalam proses ta'aruf peneliti menganalisis keterkaitan asumsi - asumsi dasar teori penetrasi sosial pada kedua jurnal yang kami teliti.

Tabel 2

Analisa pada Asumsi-Asumsi Dasar teori Penetrasi Sosial

\begin{tabular}{|c|c|c|c|}
\hline $\begin{array}{c}\text { Asumsi Dasar dari Teori } \\
\text { Penetrasi Sosial }\end{array}$ & Ridwansyah (2018) & $\begin{array}{c}\text { Fitri Sakinah dan Melok } \\
\text { Roro Kinanthi (2018) }\end{array}$ & $\begin{array}{c}\text { Shinta Galuh \& Irwa R. } \\
\text { Zarkasi (2014) }\end{array}$ \\
\hline $\begin{array}{l}\text { Hubungan-hubungan } \\
\text { mengalami kemajuan dari } \\
\text { tidak intim menjadi intim }\end{array}$ & $\begin{array}{l}\text { Pada proses ta'aruf pada } \\
\text { narasumber terjadi } \\
\text { kemajuan hubungan dari } \\
\text { tidak intim menjadi intim } \\
\text { setelah dilakukan } \\
\text { pernikahan. }\end{array}$ & $\begin{array}{l}\text { Penelitian pada jurnal ini } \\
\text { tidak menjelaskan asumsi } \\
\text { ini }\end{array}$ & $\begin{array}{c}\text { FH \& FS dan AN \& IL } \\
\text { Pada proses ta'aruf terjadi } \\
\text { kemajuan hubungan dari } \\
\text { tidak intim menjadi intim } \\
\text { setelah dilakukan } \\
\text { pernikahan. }\end{array}$ \\
\hline $\begin{array}{c}\text { Secara umum, } \\
\text { perkembangan hubungan } \\
\text { sistematis dan dapat } \\
\text { diprediksi. }\end{array}$ & $\begin{array}{l}\text { penelitian pada jurnal ini } \\
\text { tidak menjelaskan asumsi } \\
\text { ini }\end{array}$ & $\begin{array}{l}\text { penelitian pada jurnal ini } \\
\text { tidak menjelaskan asumsi } \\
\text { ini }\end{array}$ & $\begin{array}{c}\text { FH \& FS dan AN \& IL } \\
\text { Kedua belah pihak telah } \\
\text { melakukan proses orientasi } \\
\text { hingga ke tahap pertukaran } \\
\text { stabil dengan sistematis } \\
\text { serta terprediksi. Karakter }\end{array}$ \\
\hline
\end{tabular}




\begin{tabular}{|c|c|c|c|}
\hline & & & $\begin{array}{c}\text { pasangan menjadi dinamis } \\
\text { karena adanya adaptasi } \\
\text { diantara keduanya. }\end{array}$ \\
\hline $\begin{array}{l}\text { Perkembangan hubungan } \\
\text { mencakup depenetrasi } \\
\text { (penarikan diri) dan } \\
\text { disolusi }\end{array}$ & $\begin{array}{l}\text { Penelitian pada jurnal ini } \\
\text { tidak menjelaskan tentang } \\
\text { terjadi depenetrasi dan } \\
\text { disolusi pada tahap } \\
\text { hubungan informan }\end{array}$ & $\begin{array}{l}\text { Penelitian pada jurnal ini } \\
\text { tidak menjelaskan asumsi } \\
\text { ini }\end{array}$ & $\begin{array}{c}\text { FH \& FS dan AN \& IL } \\
\text { Walaupun terdapat konflik } \\
\text { dalam hubungan informan, } \\
\text { namun tidak terjadi } \\
\text { depenetrasi dan disolusi } \\
\text { pada tahap hubungan } \\
\text { informan. }\end{array}$ \\
\hline $\begin{array}{c}\text { Self-disclosure } \\
\text { (pengungkapan diri) adalah } \\
\text { inti dari perkembangan } \\
\text { hubungan }\end{array}$ & $\begin{array}{l}\text { Adanya keterbukaan dalam } \\
\text { hubungan sehingga tercipta } \\
\text { pemahaman yang sama } \\
\text { didalam proses Ta'aruf }\end{array}$ & $\begin{array}{l}\text { Penelitian kuantitatif ini } \\
\text { menemukan bahwa } \\
\text { semakin tinggi } \\
\text { pengungkapan diri (self } \\
\text { disclosure) pada proses } \\
\text { ta'aruf semakin tinggi pula } \\
\text { kepuasan pernikahan pada } \\
\text { partisipan. }\end{array}$ & $\begin{array}{c}\text { FH \& FS dan AN \& IL } \\
\text { Adanya keterbukaan diri } \\
\text { diantara kedua belah pihak } \\
\text { sehingga terciptanya } \\
\text { kesamaan perasaan dan } \\
\text { pemahaman. }\end{array}$ \\
\hline
\end{tabular}

\section{B. Pembahasan}

Dalam agama Islam, Ta'aruf secara harfiah artinya mengenal. Dalam kaitannya dengan perkawinan, ta'aruf memiliki makna yang lebih luas sebagai pranikah dimana seseorang mengenal dan mendekati pasangannya (Thobroni \& Mun, 2010)). Tujuan utama dari ta'aruf adalah untuk mengetahui dan memahami siapa yang akan dinikahi. Ta'aruf, dalam praktiknya, berbeda dengan kencan konvensional. Ta'aruf dilakukan tidak hanya antar calon pasangan tetapi dilakukan melalui pihak ketiga, seperti orang tua atau guru spiritual. Idealnya, seperti yang ditulis Thobroni dan Munir, ta'aruf harus melibatkan kedua belah pihak, laki-laki dan perempuan. Wanita memiliki hak yang sama untuk bertanya dan mengetahui tentang calon suaminya seperti halnya pria. Kejujuran sangat penting dalam proses ta'aruf.

Jika kita melihat tahapan dari teori Penetrasi Sosial itu sendiri, maka kita dapat melihat bagaimana penerapannya pada hubungan pernikahan yang didasarkan pada proses Ta'aruf. Tahap pertama yaitu tahap orientasi dimulai saat proses pengenalan dimulai bagi kedua pasangan. Awalnya, masing-masing pasangan hanya bisa mengetahui calon pasangan mereka melalui fisik / langsung dan juga $\mathrm{CV}$ masing-masing. Informasi yang dibagikan dalam CV antara lain data biografi, yang biasa dilihat dan diketahui orang lain, dan informasi-informasi umum lainnya.

Kedua calon pasangan menyebutkan kelemahan dan kelebihan, hobi serta karakteristik mereka selama proses orientasi ini. Namun, tentu ada hal yang tidak 
ditampilkan atau dilihat selama proses ta'aruf. Pertemuan yang juga didampingi oleh pihak ketiga memungkinkan mereka untuk saling menutupi informasi pribadi satu sama lain. Banyak kecemasan, penilaian dan praduga yang dialami oleh kedua pihak. Stereotip tentang ras/suku seseorang, misalnya, dapat memengaruhi penilaian tentang karakteristik calon pasangan. Hal ini tidak hanya terjadi pada pihak-pihak yang terlibat dalam ta'aruf, namun juga terjadi pada calon mertua yang akan menerima calon menantu nya. Seperti yang dipaparkan pada (Tryssa \& Zarkasi, 2018), istri dari pasangan pertama, FS, mengaku sebenarnya menghindari pria asal Minang untuk dijadikan suaminya, namun ibu FH ternyata berasal dari Minang. Dalam kasus pasangan kedua, ibu AN-lah yang cemas anaknya menikah dengan "gadis kota", apalagi mengetahui bahwa "gadis kota" yang akan dinikahi putranya adalah lulusan luar negeri dan berasal dari orang kaya, bukan. dari keluarga Jawa.

Namun, terlepas dari kecemasan dan penilaian yang terjadi selama proses ta'aruf, kedua pasangan memutuskan untuk melanjutkan ta'aruf tersebut. Kesamaan dalam keyakinan, ekspektasi religi calon pasangan, dan visi tentang pernikahan dan keluarga di masa depan dianggap lebih bermanfaat daripada kecemasan berpasangan dengan seseorang yang belum dikenal lebih dalam. Istri dari pasangan kedua pada (Tryssa \& Zarkasi, 2018) bahkan menganggap menikah dengan 'orang asing' itu menyenangkan.

Pada (Ridwansyah, 2018) proses orientasi dikaitkan kesamaan penggunaan sosial media , organisasi yang diikuti dan tempat narasumber bekerja. Berdasarkan hasil penelitian yang telah dilakukan, batasan yang ditetapkan dalam syariat islam menghambat interaksi yang dilakukan oleh pasangan yang melakukan ta'aruf. Hal ini menyebabkan komunikasi interpersonal yang berlangsung terdapat kekakuan dan kehati-hatian, adanya mediasi oleh orang yang dapat dipercaya, tidak ada penetrasi yang bersifat luas, dan menyebabkan tahapan yang dilalui hanya melewati tahap orientasi. Tahap orientasi adalah tahap dimana komunikasi yang terjadi pada saat ta'aruf lebih pada hal-hal yang bersifat umum dari masingmasing pihak. Tahapan afektif eksploratif, tahapan afektif dan tahapan pertukaran stabil dilakukan setelah menikah.

Tahapan kedua dan ketiga, Pertukaran Penjajakan Afektif dan Pertukaran Afektif dialami oleh pasangan setelah menikah. Mereka mulai mengenal pribadi "sesungguhnya" dari pasangannya setelah tinggal satu atap. Keintimannya pun berangsur-angsur meningkat, begitu pula dengan konflik dan kritik yang dituai dalam hubungan. Perbedaan budaya membuat mereka menghargai sesuatu secara berbeda.

Tahapan terakhir, yaitu tahap pertukaran stabil, mulai dialami oleh pasangan pada jurnal yang ditulis oleh (Tryssa \& Zarkasi, 2018) di satu titik tertentu. Pada narasumber pasangan pertama, hubungan mereka menjadi lebih stabil ketika pasangan ini meninggalkan rumah orang tua mereka dan tinggal di tempat mereka sendiri. Meskipun mereka masih mencoba untuk memahami pikiran dan perasaan 
satu sama lain, dan memiliki ritual baru; Namun kurangnya keterlibatan orang tua tampaknya membuat mereka tidak terlalu ragu untuk mengungkapkan perasaan emosional mereka. Mirip dengan pasangan pertama, hubungan pasangan kedua juga menjadi lebih stabil ketika mereka pindah ke Makassar, di mana tidak ada kerabat dekat. Kurangnya keterlibatan keluarga pada kedua pasangan, tampaknya membantu mereka menstabilkan pernikahan mereka, dan akhirnya berpindah ke tahap hubungan yang lebih dalam, tidak hanya secara fisik tetapi juga secara emosional.

Pada jurnal kedua yang ditulis oleh (Kinanthi \& Sakinah, 2018) yang dibahas lebih mendalam adalah tentang proses dari self-disclosure dan kaitannya dengan kepuasan pernikahan. Hasil penelitian pada jurnal tersebut menunjukkan bahwa pengungkapan diri memiliki peran terhadap kepuasan pernikahan pada individu yang menikah melalui proses ta'aruf sebesar $8,7 \%$ sedangkan sisanya sebesar 91,3\% dipengaruhi oleh faktor lain. Sebelumnya sudah ada penelitian yang dilakukan oleh (Wardhani \& Sulistyani, 2012)yang menegaskan adanya hubungan antara pengungkapan diri (self-disclosure) dengan kepuasan pernikahan. Penelitian di luar juga menemukan hubungan positif antara pengungkapan diri dengan kepuasan pernikahan.

Selain itu, pada jurnal kedua ini peneliti juga menemukan bahwa partisipan penelitian yang menikah melalui ta'aruf mampu membuka dirinya kepada pasangan nya. Hal ini berarti sejalan dengan penelitian sebelumnya yaitu pengungkapan diri memiliki peran yang erat dengan kepuasan pernikahan sehingga semakin tinggi pengungkapan diri semakin tinggi kepuasan pernikahan yang dirasakan oleh individu

\section{Kesimpulan}

Dalam penulisan ini terbukti adanya lapisan atau tahapan serta proses penetrasi sosial yang terjadi selama proses pengenalan sebelum menikah atau yang biasanya disebut Ta'aruf dalam agama Islam. Keempat tahapan penetrasi sosial dialami oleh kedua narasumber yang menjadi salah satu pedoman penulisan ini dipaparkan pada jurnal yang ditulis oleh Shinta \& Irwa. Pertama, tahap orientasi dirasakan oleh kedua individu melewati proses pertukaran $\mathrm{CV}$, resume, dan juga penilaian kasat dari fisik calon pasangan. Pengenalan suku dan budaya sebagai latar belakang calon pasangan juga kemudian akan dialami oleh individu. Tahapan kedua dan ketiga dari teori penetrasi sosial berlangsung secara bersamaan dan berangsur-angsur masuk ke tahapan terakhir di titik pertukaran stabil. Ketika tahapan kedua dan ketiga, muncul berbagai konflik dalam rumah tangga karena kedua individu sudah mulai saling mengenal satu sama lain secara lebih intim dan nyata. Namun, masalah berhasil dilewati dan masuk ke titik pertukaran stabil ketika pasangan sudah lepas dari interupsi keluarga.

Salah satu asumsi dasar dari teori penetrasi sosial adalah keterbukaan diri (selfdisclosure) adalah inti dari perkembangan hubungan. Asumsi ini juga dikemukakan bahwa pengungkapan diri terhadap kepuasan pernikahan adalah sebesar 8,7\%. Dengan 
demikian, masih terdapat 91,3\% faktor lainnya yang dapat menjelaskan kepuasan pernikahan yang dapat diteliti dalam penelitian selanjutnya.

Dalam proses self-disclosure yang terdapat pada proses ta'aruf kedua belah pihak diwajibkan untuk melakukan pengungkapan diri. Kejujuran merupakan hal yang vital pada saat pembukaan diri (selfdisclosure). Kejujuran akan menjadi fondasi utama dalam pernikahan mereka. Peneliti juga mengharapkan aspek-aspek lainnya dalam ta'aruf dapat dikaji kedepannya seperti proses komunikasi pasangan yang melakukan ta'aruf setelah pernikahan dan melibatkan mediator sebagai informan.

Berdasarkan jurnal yang telah dijadikan referensi, dapat disimpulkan bahwa kedua jurnal lainnya tidak menjelaskan keseluruhan proses penetrasi sosial. Kelemahan ketiga jurnal penelitian yang adalah tidak meneliti pengaruh durasi proses orientasi terhadap pengurangan ketidakpastian pada proses ta'aruf. Peneliti berharap akan ada penelitian lanjutan yang membahas topik digitalisasi proses ta'aruf yang mulai digunakan sebagai mediator berupa website seperti Mawaddah Indonesia.

\section{BIBLIOGRAF}

Agustin Wulandari, Tine. (2013). Memahami Pengembangan Hubungan Antarpribadi Melalui Teori Penetrasi Sosial. Majalah Ilmiah Unikom.

Altman, Irwin, \& Taylor, Dalmas A. (1973). Social penetration: The development of interpersonal relationships. Holt, Rinehart \& Winston.

Beebe, S., Beebe, S., Redmond, M., Geerinck, T. M., \& Salem-Wiseman, L. (2011). Interpersonal communication: relating to others 7 th edn. Allyn \& Bacon Boston, MA; Columbus, IN.

Jiang, Chengxin, Yang, Yingjie, \& Zheng, Yong. (2014). Penetration of mid-crustal low velocity zone across the Kunlun Fault in the NE Tibetan Plateau revealed by ambient noise tomography. Earth and Planetary Science Letters, 406, 81-92.

Kinanthi, Melok Roro, \& Sakinah, Fitri. (2018). Self-disclosure, family resilience, and marital satisfaction among Moslems who married through ta'aruf process. Asian Association of Indigenous and Cultural Psychology, Sabah, Malaysia.

Ridwansyah, Muhammad. (2018). Upaya Menemukan Konsep Ideal Hubungan PusatDaerah Menurut Undang-Undang Dasar Negara Republik Indonesia Tahun 1945. Jurnal Konstitusi, 14(4), 838-858.

Shanaz, Nadya Valerie. (2021). Teori Penetrasi Sosial dalam Pengungkapan Diri 
Homoseksual kepada Keluarganya. JRK (Jurnal Riset Komunikasi), 11(2).

Siddiqi, M. Yaeesh, \& Glass, Anthony D. M. (1981). Utilization index: a modified approach to the estimation and comparison of nutrient utilization efficiency in plants. Journal of Plant Nutrition, 4(3), 289-302.

Suryabrata, Sumadi. (1998). Metodelogi penelitian. Jakarta: Raja Grafindo Persada.

Thobroni, Munir, \& Mun, Aliyah A. (2010). Meraih berkah dengan menikah. Pustaka Marwa.

Tryssa, Shinta Galuh, \& Zarkasi, Irwa R. (2018). Communication in Intercultural Marriage: The Application of Social Penetration Theory among Couples Preceded by Ta'aruf.

Wardhani, Lilies Kusuma, \& Sulistyani, Nanik. (2012). Uji Aktivitas Antibakteri Ekstrak Etil Asetat Daun Binahong (Anredera Scandens (L.) Moq.) terhadap Shigella flexneri Beserta Profil Kromatografi Lapis Tipis. Jurnal Ilmiah Kefarmasian, 2(1), 1-6.

West, Keon, \& Turner, Rhiannon. (2014). Using extended contact to improve physiological responses and behavior toward people with schizophrenia. Journal of Experimental Social Psychology, 50, 57-64.

Wulandari, Deasy, \& Subagio, Ari. (2015). Consumer decision making in conventional banks and islamic bank based on quality of service perception. Procedia-Social and Behavioral Sciences, 211, 471-475. 